\title{
Fielding questions of age and experience: Honesty is the best policy
}

\author{
Mara B. Antonoff, MD, FACS
}

\footnotetext{
From the Department of Thoracic and Cardiovascular Surgery, University of Texas MD Anderson Cancer Center, Houston, Tex.

Disclosures: Author has nothing to disclose with regard to commercial support.

Received for publication April 19, 2017; accepted for publication April 21, 2017; available ahead of print May 31, 2017.

Address for reprints: Mara B. Antonoff, MD, FACS, 1400 Pressler St, Unit 1489, Houston, TX 77030 (E-mail: mbantonoff@mdanderson.org).

J Thorac Cardiovasc Surg 2017;154:568-9

$0022-5223 / \$ 36.00$

Copyright (c) 2017 Published by Elsevier Inc. on behalf of The American Association for Thoracic Surgery http://dx.doi.org/10.1016/j.jtcvs.2017.04.047
}

When is a doctor too old, and when is a doctor too young? This fascinating question was the topic of an essay in The New York Times, highlighting sharp contrasts between 2 physician colleagues who graduated from medical school more than 40 years apart. ${ }^{1}$ Written to emphasize artistically the differences between generations, the essay brings to light a very important issue: we, as physicians, will continually be questioned by patients, families, payers, and the public regarding our competency and expertise. The most famous, experienced, and esteemed surgeons may some day need to answer questions such as, "Are you still operating?" Likewise, the brightest, most talented graduates from top-tier training programs, familiar with cuttingedge techniques and bubbling over with information absorbed from wise mentors and board review books, may find themselves answering questions about their age and their readiness for independent practice. Issues surrounding the latter of these circumstances are discussed in this issue's Young Surgeon's Note by Krantz and Merritt-Genore. ${ }^{2}$

In this article, Krantz and Merritt-Genore ${ }^{2}$ provide excellent advice for fielding questions related to surgeon age and experience in a professional, honest manner. Sometimes these exchanges are entirely appropriate and anticipated ("Can you tell me how many of these operations you've personally performed?"), whereas other comments may be out-of-line and catch the surgeon off-guard ("You're so young and cute, you must have come straight from your high-school prom.') Regardless of the tone or intent of the questioning, it is imperative that we, the professionals, be prepared to handle inquiries from patients, family members, and even some colleagues in a manner that will inspire confidence in our abilities. Ultimately, regardless of anyone's preconceived notions, surgeons who exude knowledge and technical expertise will likely be recognized appropriately for their skills and aptitude.

Krantz and Merritt-Genore ${ }^{2}$ provide several helpful suggestions on how to handle a variety of scenarios. They give practical tips, such as being aware of your own case

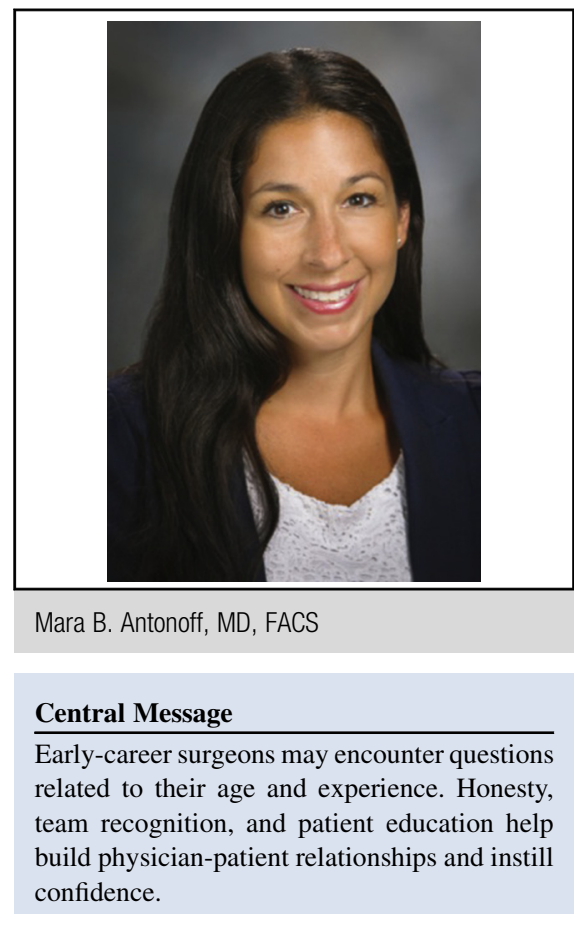

See Article page 565 .

numbers and outcomes. Further, they offer advice on relating to patients, so that they are comforted and feel at ease with their clinician, even if first appearances may have been (fairly or unfairly) off-putting. They discuss finding common ground with your patients and their families, as well as taking the time to elaborate on issues related to the specific case. In addition, they discuss acknowledging the experience of the entire team, which not only takes the pressure off the exact quantifiable, measurable amount of the experience of the young surgeon but also-and importantly-gives credit to the multidisciplinary team members who enable your success. Not only will humility and appreciation for your team instill patient confidence, these attitudes will help build great working relationships and team loyalty. Following the recommendations from this article will simultaneously help the young surgeon impart confidence in his or her skeptics and encourage him or her to become a better doctor. Putting patients at ease by making a personal connection and educating them regarding their procedures will, one hopes, result in more patient confidence than that provided by sheer number of gray hairs on your head. Further, these communication strategies are 
generally just great advice for improving patient satisfaction and minimizing malpractice risk.

Patient evaluations of their health care experiences are becoming increasingly important to the public and payers, and consequently more relevant to our practices. High patient satisfaction is associated with increased market share, financial gains, decreased malpractice claims, and improved reimbursement rates. ${ }^{3}$ There are numerous ways in which surgeons may aim to optimize patient satisfaction, several of which are pragmatically described in this Young Surgeon's Note. ${ }^{2}$ Experts in patient satisfaction have described strategies related to physician-patient communication and setting expectations, which fall in line with the guidance provided by Krantz and Merrit-Genore. ${ }^{2,3}$

Also quite timely, this article delves into issues of expectations regarding a surgeon's appearance. Much attention has been given lately to how a surgeon may look, with social media efforts and news releases directed toward educating the public regarding the diversity of practicing surgeons in terms of sex, race, and age. ${ }^{4}$ Movements such as \#ILookLikeASurgeon and The New Yorker OR Cover Challenge have tried to change the public's perception of what they might expect when they arrive in the surgeon's office. These movements are especially powerful in the field of thoracic surgery, where women represent such a small minority. As the face of thoracic surgery continues to change, young surgeons (as well as women surgeons, aging surgeons, and underrepresented minorities) must recognize that they may not be what the patients are expecting. The task at hand for all of us, however, is to change and exceed those expectations.

The conclusion of this article certainly merits highlighting. Krantz and Merritt-Genore ${ }^{2}$ remind us, "In the end...the patient always comes first. If there are any doubts about your own ability to provide the best operation and postoperative care, both personally and institutionally, make sure that the patient gets the right care." They advise the readers to know their own limits. These closing statements are right on. On the one hand, as a newly practicing surgeon, you want to prove that you are capable. Understandably, you do not want the patient to underestimate you. But, first and foremost, you certainly do not want to overestimate yourself. Patient safety is always number one, and everything else is secondary. If you need help, put your ego aside and advocate for your patient. This course of action will actually give the patient much more confidence in you than if you try to do something risky alone. After all, no patient has ever said, "I'd rather have 1 competent surgeon than $2 . "$

\section{References}

1. Zuger A. When is a doctor too old? Or too young? The New York Times. February 8, 2005: F5.

2. Krantz S, Merritt-Genore HM. How old are you, and how many of these have you done? Fielding questions of age and experience in your early career. $J$ Thorac Cardiovasc Surg. 2017;154:565-7.

3. Shirley ED, Sanders JO. Patient satisfaction: Implications and predictors of success. J Bone Joint Surg Am. 2013;95:e69.

4. Hughes KA. \#ILookLikeASurgeon goes viral: How it happened. Bull Am Coll Surg. 2015;100:10-6. 